University for Business and Technology in Kosovo

UBT Knowledge Center

Oct 27th, 1:30 PM - 3:00 PM

\title{
Translation aspects of brothers Grimm Fairy Tales and comparison to translation between English and Albanian version
}

\author{
Redi Papa \\ University for Business and Technology, redi.papa@ubt-uni.net \\ Halil Bashota \\ University for Business and Technology, halil.bashota@ubt-uni.net
}

Follow this and additional works at: https://knowledgecenter.ubt-uni.net/conference

Part of the Education Commons

\section{Recommended Citation \\ Papa, Redi and Bashota, Halil, "Translation aspects of brothers Grimm Fairy Tales and comparison to translation between English and Albanian version" (2018). UBT International Conference. 142. \\ https://knowledgecenter.ubt-uni.net/conference/2018/all-events/142}

This Event is brought to you for free and open access by the Publication and Journals at UBT Knowledge Center. It has been accepted for inclusion in UBT International Conference by an authorized administrator of UBT Knowledge Center. For more information, please contact knowledge.center@ubt-uni.net. 


\title{
Translation Aspects of Brother Grimm Fairy Tales and comparison to translation between English and Albanian Version
}

\author{
Redi Papa ${ }^{1}$, Halili Bashota ${ }^{2}$ \\ 1,2 UBT - Higher Education Institution Str. Lagjia Kalabria p.n., 10000 Prishtinë, \\ Kosovo
}

Redi.papa@ubt-uni.net, halil.bashota@ubt-uni.net

\begin{abstract}
The main aim of this paper is to provide an in depth analysis regarding some of the underlying translation aspects of Brother Grimm Fairy Tales. The paper will closely elaborate and make comparison to translation between English version and Albanian version. Due to the fact that translation in itself is a multidisciplinary field of study, its reasonable tackling and profoundly analyzing some of the core stylistic features of this genre as well as carry out an elaboration of lexical components will a special emphasis on synonymy, phraseology and metaphors. Undoubtedly, the paper also incorporates and interweaves methods of translation, aspects related to equivalence in translation and the qualities of a translator needed to translate literature for children, which is quite peculiar compared to other genres. Owing to the fact that it vastly copes with analysis of lexical and translation traits of the respective piece, the method of research employed in this paper it is basically a qualitative one. Translation is also closely related to culture which means that translator may frequently have to cope with cultural words, proverbs which may hamper the process of translation in its entirety, as matter of fact a section of this paper will be also devoted to this issue.
\end{abstract}

Key words: equivalence in translation, synonymy, comparison, methods of translation, style, lexical components. 


\section{Introduction}

Brother Grimm fairy tales bring us back to the world of fairies, witches and goblins. These tales are worldwide known for their memorable characters as well as aesthetical and emotional colorings. The tales may be referred to as a wild mixture as "The Rich Man's grave, where it's witnessed a rigid combination between fantasies, religion or as gruesome such as "The robber Bridegroom". Nevertheless some of their tales are comprised of a sense of humor and nonsense such as in "Clever Grethel". Obviously, folklore in itself obtains artistic and lingual traits not only because it is mainly created and further on inherited in successive generations.

In the course of $19^{\text {th }}$ century Jakob and Wilhelm Grimm brought forth a collection of fairy tales aiming at representing the features of German culture. Contrary to other authors who had consistently strived for altering and somehow embellishing the stories to suit to the audience, Grimm's may be considered to be the first collectors who maintained a "strict allegiance" with the original tales and preserved their true value bearing in mind that the true strength relies on authenticity.

A distinctive trait of these tales is that they were targeted to all ages meaning that there was no age-restriction. Images, emotions and beings we associate with the primitive or childlike mind involve; fairies, sorcerers, magic and mystery, great joy, and fear are everyday experiences. Indeed, Grimm's have the unarguable merit that through their masterpiece have masterfully reflected the emotions and desires of every human being.

Nevertheless, the underlying function of the language in artistic literature is its aesthetic function a quality which is clearly mirrored in the Grimm's masterpiece. This means that language in itself does not merely incarnates or is comprised of certain content as well as it doesn't simply communicate literary information but aims at having an aesthetic function and evoke the feeling of beauty. Translation of these tales is not an easy matter and it requires a mastery of source and target language as well as a broad lexical diapason. Beside that the translator ought to carry out an interpretation rather than a word-for-word translation, which would rather convey the emotions, pleasure of the stories and the all their utmost variety.

\section{The traits and qualities of a Translator when it comes to translating artistic texts and tales}

Translation is an intricate and complex process in itself, owing to the fact that it is a multidisciplinary field of study. When it comes to translating a text at utmost 
proficiency it's indispensable to analyze the source text linguistically, culturally, philosophically and politically. The translation scholar Robinson $(1997 ; 199)$, emphasizes that a translator must bear in mind the following elements; a)never assume you understand the source text perfectly $b$ )never assume your understanding of the source text is detailed enough to enable you to translate it adequately. c)always analyze for text type, genre, register, rhetorical function, etc. d) always analyze the source text's syntax and semantics, making sure you know in detail what it is saying, what it is not saying, and what it is implying e)always analyze the syntactic, semantic, and pragmatic relationship between the source language (especially as it appears in this particular source text) and the target language, so that you know what each language is capable and incapable of doing and saying, and can make all necessary adjustments.

Whereas the translation scholar Tupe (2006;22), argues that a translator who strives for perfection must render the following qualities: a) to have at least a comprehensive basic knowledge of the target language b) must be able to analyze and understand a text or a given speech c) capable to carry out not only a linguistic, but even a interpretative translation d) an enriched lexicon and vocabulary, that exceeds the linguistic framework, which is in other words called "overall culture" which is sustained by an eager curiosity and a strong memory. Consequently, it means to cognize the history, culture, the social and artistic life the respective population, from whose language you want to translate; whereas it is also necessary to acquire some information about their lifestyle, e) to approach to translation as an art, technique science and profession, $f$ ) to have a strong passion and be gifted in reading, comprehending, speaking, writing and creating when asked to translate from source to target language g) lastly, what is considered as one of the underlying features of a professional translator is that he must be fostered by a insight curiosity, concerning the world that surrounds him.

However one of the underlying components of a translator is knowledge and as matter of fact Roger (1991;31), argues that a knowledge base consisting of;

- Source language knowledge, the syntactic rule systems code, its lexicon and semantics, and its text creating systems

- Target language knowledge, equivalent to the source language

- $\quad$ Text-type knowledge

- Domain knowledge

- Contrastive knowledge of each above

As far as the four main areas and skills are concerned Roger (1991;31), distinguishes the following competences;

- Grammatical Competence; knowledge of the rules of the code, including vocabulary and word formation, pronunciation/spelling and sentence structure and knowledge and skills required to understand and understand literal meaning of utterances 
- $\quad$ Sociolinguistic Competence; knowledge and ability to understand the utterances properly, such as constrained by topics, the status of participants and purposes of interaction

- Discourse Competence;

- Strategic Competence the ability to combine form and meaning to achieve unified spoken or written texts in different genres, this unity depends from cohesion in form (the way which utterances are linked structurally to facilitate the interpretation of the text) and coherence in meaning (the relationship between different meanings) such as literal meanings, communicative functions, social functions and literal meanings

- $\quad$ Strategic Competence; the mastery of communication strategies which may be used to improve communication or to compensate for breakdowns (caused by limiting factors in actual communication to insufficient competence in one or more of the other components of communicative competence)

\section{Translation English-Albanian of some paragraphs from "The Complete Brother Grimm fairy Tales", fully Illustrated", Gramercy Books, New York, 1981.}

In olden times when people could have all they wished for at once, lived a king who had many beautiful daughters; but the youngest was so lovely that the sun himself would wonder whenever he shone on her face. Near to the kings castle lay a dark gloomy forest, in the midst of which stood a linden tree, shading with its foliage the pleasant waters of the mountain. Grimm $(1981 ; 1)$.

Translation in Albanian

Në kohët e vjetra, atëherë kur njerëzit mund të kishin cfarë dëshironin sa hap e mbyll sytë, jetonte një mbret $i$ cili kishte shumë vajza të bukura; por vajza e vogël ishtë aq e hijshme sa edhe dielli magjepsej kur shihte shndërriste në fytyrën e saj. Pranë kështjellës së mbretit shtrihej një pyll i zymtë, $i$ errët, në krye të cilit ndodhej një pemë blini e cila hijëzonte me gjethet e saj ujërat e qeta të një shatërvani që ndodhej pranë.

Near the borders of a large forest dwelt in olden times a poor woodcutter, who had two children Hansel and Gretel. They had very little to live upon, and once when was a dreadful season of scarcity in the land, the poor woodcutter could not earn sufficiently to supply their daily food. One evening after the children were gone to bed, the parents sat talking together over their sorrow, and the poor husband sighed and said to his wife who was not the mother of their children but their stepmother, What will become of us, for I 
cannot earn enough to support you and myself, much less the children? What shall we do with them for they must starve? Grimm $(48 ; 1981)$.

Translation in Albanian

Në kohët e vjetra në afërsi të sinorëve mes dy pyjeve të dendur jetonte një druvar $i$ varfër $i$ cili kishte dy fëmijë Hansin dhe Gretën. Ata ishin shumë të varfër dhe me vështirësi arrinin të siguronin kotherren e bukës. Mjerimi i kaploi dhe u shtua këmbëkryq në sofrën e tyre kur pas një acari të kobshëm toka mbeti djerrë dhe druvari i sfilitur me mundim të madh arrinte të siguronte bukën e përditshme. Një ditë kur fëmijët kishin shkuar në shtrat për të fjetur, burrë e grua u ulën pranë njëri-tjetrit të brengosur dhe nisën fill të flisnin për mjerimin që i kishte kapluar. Ndërkaq, burri pshërrëtiu duke i thenë së shoqes e cila nuk ishte nëna e fëmijëve por njerka e tyre. "Cfarë do të behët me ne, unë nuk po arrij të fitoj mjaftueshëm te nxjerr jetesën ne të dy, aq më pak për fëmijët? Cfarë të bëjmë me ta për të mos i lënë të vdesin urie?

Paragraphs in another English Version Brother Grimm Fairy Tales, Pantheon Books, New York 1944.

In olden times when people when wishing still helped one, there lived a king whose daughters were all beautiful, but the youngest was so beautiful than the sun himself, which has seen so much was astonished whenever it shone in her face. Close by, the King's castle laid a great dark forest, and under an old lime tree in the forest was a well.

Translation in Albanian

Në kohët e vjetra kur lutjet e njerëzve bëheshin realitet, jetonte një mbret, vajzat e të cilit ishin të bukura, por me e reja mes tyre ishte aq hijshme saqë edhe vet dielli, i cili ishte mësuar të shihte shumë shtangej prej bukurisë sa herë shndërriste në fytyrën e saj.

By a great forest dwelt a poor woodcutter with his wife and two children. The boy was called Hänsel and the girl Gretel. He had little to bite and to break, and once when great dearth fell on the land, he could not even procure his daily bread. Now when he thought over this by night in his bed and tossed about in his anxiety, he groaned and said to his wife, "What is to become of us?

Translation in Albanian

Në një pyll të madh jetonte një druvar sëbashku me të shoqen dhe dy fëmijët, emrat e të cilëve ishin Hansi dhe Greta. Atij i duhej të punonte pa rreshtur për të siguruar bukën e fëmijëve. Mirëpo një ditë prej ditësh kur pllakosi zia e bukës nuk ishte më në gjendje të siguronte as bukën e përditshme. I brengosur prej pikëllimit sillej sa andej këndej në shtratin e tij, kur më në fund i foli disi me rënkim gruas së tij, "Si do shkojë puna jonë ?" 


\section{Methods of Translation}

Obviously, in translation of Brother Grimm Fairy Tales is witnessed an interweaving between faithful method of translation and adaption when time after time they appear to overlap each other. As Newmark argues (1998;46),

"A faithful attempts to reproduce the precise contextual meaning of the original within the constraints of the TL grammatical structures. It 'transfers' cultural words and preserves the degree of grammatical and lexical 'abnormality' (deviation from SL norms) in the translation. It attempts to be completely faithful to the intentions and the textrealization of the $S L$ writer. Faithful translation which aims at preserving the grammatical and syntactical forms of the original statements. The main purpose of this method is to provide a text which is less ambiguous and less complex than the source text. This sort of translation is distinguished for taming and simplifying the ambiguity which is apparent in the source text. Consequently, to enable this are added explanations, shortenings of sentences and it is reduced the lexical density."

Indeed there has been witnessed a faithful translation of the adjective woodcutter with the Albanian equivalent druvar, or the noun foliage with the Albanian equivalent gjethe and the adjective astonished with the Albanian equivalent shtangej.

Implementation of Adaption as a translation method was unavoidable in some cases when the translator has to cope with phraseology or idioms. Adaption as Newmark $(1998 ; 46)$ argues," Is the 'freest' form of translation. It is used mainly for plays (comedies and poetry; the themes, characters, plots are usually preserved, the SL culture converted to the TL culture and the text rewritten. The deplorable practice of having a play or poem literally translated and then rewritten by an established dramatist or poet has produced many poor adaptations, but other adaptations have rescued period plays. Adaption occurs when something specific to one language culture is expressed in a totally different way that is familiar or appropriate to another language or culture. It is a shift of cultural environment."

In translation from English to Albanian Adaption has been incorporated as a method of translation only in some specific cases, such as in translation the a great dearth fell on land to its Albanian equivalent në tokë ra zia e bukës ose pllakosi zia e bukës or in the sentence he had little to bite and break with the Albanian equivalent I duhej te punonte shumë për të siguruar bukën e përditshme. 


\section{Theories of Equivalence in Translation}

Jacobson's Equivalence Theories: R.Jakobson (1959), believes that equivalence comes in three types; inter-semiotic equivalence, (equivalence between sign systems), inter-lingual (equivalence between two languages), and intra-lingual, (equivalence within one language; paraphrasing or rewriting the same content). The second type, intra-lingual, is one where translation equivalence is classified in. In the brother Grimm Fairy "Tale Frog Prince" in a paragraph there is a sentence; "He had little to bite and break" which may be easily rephrased and re-written in English. "He could hardly make the ends meet, "He could scarcely earn living" or "He was on verges of starvation", "He could barely find a morsel of bread", "They had very little to live upon", "Could not earn sufficiently to supply their daily food". Undoubtedly, all those versions render a similar meaning. This rephrasing is the best example of intra-lingual equivalence.

Nida Equivalence Theories: Conversely, E.A Nida (1964), has written that there are two kinds of equivalence; a) formal equivalence (also known as formal correspondence), and dynamic equivalence. Formal equivalence is more concerned with word-for-word translation and content faithfulness, while dynamic equivalence is focused upon context and sense-for-sense adaption.

The bottom line here is that all translation theories are somehow connected with the notion of equivalence in one way or another. Consequently, equivalence is an important philosophy when it comes to translation theory and its many different practical applications. Actually, both target and source language include equivalent ranges from the least significant morphemes to the most meaningful levels (sentences).

These levels of language are the ones that keep the ones that help strike the proper balance between two much faithfulness to the original text and too much pandering to the target audience. Accordingly, translation is all about creating a balance between the original language document and the target language document.

It is generally agreed so far that meaning is very important in translation (Catford, 1965: 35). Indeed translation has often been defined with relevance to the meaning. According to this approach, a translation ought to have the same meaning with the original, but should not sound like a translation. As far as this issue is concerned, I will provide my own illustrations about between English and Albanian versions and respectively to point out which is distinguished as a translated text and which not. The case of meaning is in fact conventionally packaged in the languages, either source or target language. What's important to be mentioned is that each language has its distinctive forms and traits, and as matter of fact translators have to perceive and realize that not all elements of a language are have their equivalents in the other language. Therefore finding 
the equivalence may be considered one of the main obstacles which are commonly faced by the translators.

Whereas Eco $(2001 ; 20)$ argues that there cannot be a complete equivalence in meaning. Equivalence in meaning cannot be taken as a satisfactory criterion for a correct translation, first of all because in order to define the still undefined notion of translation one would have to employ a notion as obscure as equivalence of meaning, and some people think that meaning is that which remains unchanged in the process of translation. We cannot even accept the naive idea that equivalence in meaning is provided by synonymy, since it is commonly accepted that there are no complete synonyms in language. He's probably come up to the right conclusion. Practically there may not be provided a full equivalence even in Brother Grimm tales. For example the names of personages such as "Hansel and Gretel" may be translated in Albanian "Hansi dhe Greta" ose "Rita dhe Hasani", which unavoidably leads do a distortion of the original meaning. Other examples may also be "Frog Prince" translated in Albanian "Princi Bretk", The Three Little Man in the Wood translated in Albanian as "Të tre Shkurtabiqët" etc, or "The Brave Little Tailor" translated in Albanian as "Terziu Guximtar", The cat who married a Mouse" as "Macja dhe Miu”.

\section{Translation of Metaphors}

Metaphor emphasizes Newmark $(2001 ; 99)$ argues that metaphor is based on a scientific procedure and the perception or resemblance between two phenomena. Moreover he emphasizes that when a metaphor is repeated in various contexts, the emotive effect subsides and a term that describes reality has been more closely created. In the translated paragraphs may be easily pointed out the metaphor dearth fell on the land translated in Albanian ra zia e bukës. Mostly metaphors render and are distinguished for these two qualities a) personification which are considered anthropomorphic and b) mental and physic. Their common feature is that they both reinforce the emotive effect. Obviously another metaphor which has simultaneously anthropomorphic and personification traits is but the youngest was so beautiful than the sun himself, which has seen so much was astonished whenever it shone in her face it is translated in Albanian por me e reja mes tyre ishte aq hijshme saqë edhe vet dielli, $i$ cili ishte mësuar të shihte shumë shtangej prej bukurisë sa herë shndërriste në fytyrën e saj. In addition, In The Complete First Edition, The Original Folk \& Fairy Tales of The Brother Grimm, Princeton University Press, 2014, in the tale "The Companionship between Cat and Mouse" is witnessed the presence of some metaphors such as

"Swallowed it in one gulp" which is translated in Albanian as "E gllabëroi me një fryme" or "E gllabëroi sa hap e mbyll sytë." 


\section{Conclusions}

Due to the fact that translation is a complex and intricate process a translator ought to render the following qualities;

- Source language knowledge, the syntactic rule systems code, its lexicon and semantics, and its text creating systems

- Target language knowledge, equivalent to the source language

- $\quad$ Text-type knowledge

- Domain knowledge

- Contrastive knowledge of each above

to have at least a comprehensive basic knowledge of the target language,

- must be able to analyze and understand a text or a given speech

- capable to carry out not only a linguistic, but even a interpretative translation

- an enriched lexicon and vocabulary, that exceeds the linguistic framework, which is in other words called "overall culture" which is sustained by an eager curiosity and a strong memory. Consequently, it means to cognize the history, culture, the social and artistic life the respective population, from whose language you want to translate; whereas it is also necessary to acquire some information about their lifestyle

- to approach to translation as an art, technique science and profession,

- to have a strong passion and be gifted in reading, comprehending, speaking, writing and creating when asked to translate from source to target language

- Lastly, what is considered as one of the underlying features of a professional translator

- The method of translation is that of faithful translation

- A faithful attempts to reproduce the precise contextual meaning of the original within the constraints of the TL grammatical structures. It 'transfers' cultural words and preserves the degree of grammatical and lexical 'abnormality' (deviation from SL norms) in the translation. It attempts to be completely faithful to the intentions and the text-realization of the SL writer. Faithful translation which aims at preserving the grammatical and syntactical forms of the original statements

- A distinctive trait of these tales is that they were targeted to all ages meaning that there was no age-restriction. Images, emotions and beings we associate with the primitive or childlike mind involve; fairies, sorcerers, magic and mystery, great joy, and fear are everyday experiences. Indeed, Grimm's have the unarguable 
merit that through their masterpiece have masterfully reflected on the emotions and desires of every human being.

- Obviously, folklore in itself obtains artistic and lingual traits not only because it is mainly created and further on inherited in successive generations.

\section{Bibliography}

1. Bell, R. (1991). "Translation and Translating, Theory and Practice”, Longman, New York.

2. Catford, J.G. (1965). “A Linguistic Theory of Translation”, Oxford University Press, London.

3. Eco, U. (2001). "Experiences in Translation", University of Toronto Press, Toronto.

4. Jacobson, R. (1959). “On Linguistic Aspects of Translation”, essay.

5. Newmark, P. (2001). "Approaches to Translation”, Shanghai Foreign Language Language Education Press", Shanghai, 2001.

6. Newmark, P. “A Textbook of Translation," New York Prentice Hall.

7. Nida, E. (1964). "Towards a Science of Translating" Leiden E.J Brill.

8. Robinson, D. (1997). "Becoming a Translator", Routledge, London.

9. Tupe, E (2007). "Këshilla një Përkthyesi të ri”, Onufri, Tiranë.

10. "The Complete Brother Grimm fairy Tales", fully Illustrated", Gramercy Books, New York, 1981.

11. "The Complete Brother Grimm Fairy Tales", Pantheon, New York, 1944.

12. "The Complete First Edition, The Original Folk \& Fairy Tales of The Brother Grimm", Princeton University Press New York, 2014. 